Anna Kern \& Marc Hooghe

\title{
The Effect of Direct Democracy on the Social Stratification of Political Participation: Inequality in Democratic Fatigue?
}

\author{
Comparative European Politics, forthcoming \\ (C) Comparative European Politics
}

\begin{abstract}
The literature on participatory democracy suggests that citizens' direct democratic involvement will be associated with higher levels of democratic legitimacy. Simultaneously, however, it has been pointed out that a repeated reliance on direct democracy procedures might lead to democratic fatigue among citizens, and it might even lead to a 'participation paradox', as a proliferation of forms of participation in practice leads to more inequality. In this paper we investigate to what extent direct democracy indeed has an effect on participation levels. Only for voting we find that direct democracy has a direct dampening effect. Also, for non-institutionalized forms of political participation we find that citizens with a low socio-economic status are even less likely to participate when they live in a country where direct democratic instruments are extensively available. We close with some observations on what effect direct democracy might have on the overall functioning of representative democracy.
\end{abstract}

Keywords: direct democracy, comparative research, political participation, stratification 


\section{Introduction}

Within the literature, various authors have claimed that an expansion of the political participation repertoire that is available to citizens, might serve as an ideal manner to counter the alleged loss of legitimacy of representative politics (Saward, 2003; Tormey, 2015). It has been argued that if public policy is expected to correspond to citizens' preferences, the best way to achieve such a congruence is by involving citizens more directly in the decision-making process (Budge, 1996). Examples that have been mentioned in this literature are the introduction of deliberative democracy, efforts to get citizens involved in local projects or participatory budgeting, and a wider use of direct democracy initiatives. Indeed, the number of referendums in liberal democracies has been expanding continuously over the past decades as more governments seem to be confronted with a problem of democratic legitimacy (Qvortrup, 2014). There seems little doubt that in these democracies there is a demand by at least some groups of the population to expand the opportunities they have at their disposal to get their voice heard in the process of political decision-making (Dalton \& Welzel, 2015).

Traditionally, however, it is assumed that increasing participation opportunities might increase patterns of inequality. The 'participation paradox' argument as it was introduced by Verba and Nie (1972) claims that more intense forms of political participation will be used mainly by the more privileged groups within society, that already have more opportunities to have an impact on political decision making. Subsequent research has indeed confirmed that this participation paradox to a large extent determines patterns of social stratification in political activity (Schlozman, Verba \& Brady, 2012). Marien, Hooghe and Quintelier (2010) have shown that the social stratification of participation in new and emerging forms of political participation is much stronger than the stratification one typically finds among institutionalized forms of participation. Their analysis suggests that levels of education function as the most important determinant of stratification, as the new forms of participation often have in common that they require a rather high level of cognitive resources, and these resources are not available in an equal manner across the population (Nie, Junn \& Stehlik-Barry, 1996). Expanding the opportunities to participate, therefore, would in practice predominantly benefit the well-off (Verba, 2003).

Other authors, however, have made exactly the opposite claim. Kriesi (2004) and Tarrow (1998) depart form the notion that the opportunities being offered by the political system to a large extent 
determine whether or not citizens will participate in the political process. Their assumption is that the more, and the more diverse opportunities there are, the larger the segment of the population that will actually participate. Theoretically this is in line with the Lijphart (2012) argument that a more open political system, i.e., a political system with more opportunities for power sharing, will lead to a more equal distribution of political power across the population. Given these opposing points of view, it is therefore highly relevant to ascertain what are the effects of the availability of direct democracy procedures within a country.

We know from previous research that the participation paradox is present among the more intensive forms of democratic innovation, like deliberative democracy. In that case, participants indeed need rather high levels of political interest and knowledge (Grönlund, Herne, \& Setälä, 2015). Social conventions on public discourse, too, might narrow the opportunities for specific groups of the population to achieve full equality in deliberative settings (Young, 2001). While proponents of deliberative democracy state that deliberative democracy increases the quality of democracy, other authors have argued that this form of innovation might in fact lead to cumulative forms of inequality (Hooghe, 1999). Obviously, political deliberation can be considered as a timeconsuming form of participation, that also requires quite some social and discursive skills. The question however, is whether the participation paradox can also be found for forms of participation that seem more accessible, even to those who have fewer political resources. At first sight, it is less evident that exactly the same mechanism would be present for direct democracy. In most cases, experiences with direct democracy remained limited to a referendum, where a simple yes/noanswer is all that is required from participants. This would not require all that much sophistication, while a limited participation act like this is also less likely to lead to democratic fatigue. Nevertheless, some of the research for Switzerland (Kriesi, 2008) clearly suggests that for referendums too, especially the lower educated refrain from participating. What is even more troubling is that there might be a spill-over effect: the proliferation of referenda not only leads to lower levels of participation in the referenda themselves, but also spills over into electoral participation (Freitag \& Stadelmann-Steffen, 2010). Again the Swiss case stands out in this respect: while the country boasts itself as the best example of practicing direct democracy, voter turnout levels for parliamentary elections typically are below 50 per cent, which is remarkably low for European standards. 
Thus far, however, we do not have sufficient evidence to arrive at a conclusion about the full democratic potential of direct democracy, and the effect it has on the social stratification of political participation in general. On the one hand, the availability of direct democratic instruments provides citizens with an additional entry point to the political system that is in principle available to all citizens, thus leading to more equal participation (Lijphart, 2012). On the other hand, this additional instrument also adds to the complexity of the political system and might induce a participatory fatigue that is most noticeable among those that are least likely to participate in the first place (Verba, Schlozman \& Brady, 1995). In this article, therefore, we analyze the relation between the availability and the use of direct democracy in a country, and the stratification of various political participation acts. We focus on stratification because the alleged goal of representative democracy is to ensure that all group within the population receive an equal opportunity to have their interests represented in politics. If this ideal is not realized, obviously political systems do not live up to the expectation of providing equal voice to all their citizens (Roemer, 2000).

We aim to contribute to the currently available literature, because the empirical research on the effects of direct democracy thus far has been inconclusive. Dalton and Weldon (2013, p. 59) even state: "The estimated effects of direct democracy are typically weak across various citizenship measures. (...) But most effects are no statistically significant and tend to vary across different indicators of national usage of direct democracy." It is therefore important to contribute solid empirical insights into this debate that, thus far, has been conducted primarily on normative grounds. In this article we start from the assumption that one of the reasons for the non-findings might be that in previous research effects have not been differentiated. However, we can assume that different groups within the population react differently to the incentives given by the political system. Depending on how these differences work out, these might strengthen or reduce inequalities within the population. This might suggest a trade-off effect. It might be that direct democracy is associated with some positive attitudinal effects, but the downside for this might be a larger degree of inequality in what groups within society get their voices heard within political decision-making.

In this paper, we first review the literature on the effects of direct democracy, before we present our data and methods. Following the results section, we reflect on what this implies for the democratic potential of direct democracy initiatives. 


\section{Literature}

In the literature, it is routinely assumed that experiences with direct democracy have a positive effect on democratic attitudes (Qvortrup, 2014), although it has to be noted that these effects might be moderated by personality characteristics (Freitag \& Ackermann, 2016). There is indeed a strong research line, departing from the notion that experiences with democratic procedures would lead to a subsequent rise in, e.g. political trust or political efficacy. The guiding idea is that participation and power-sharing are empowering experiences, that should be associated with a more positive attitude toward the political system in general. If citizens have had the experience that they have participated in the decision-making process in a meaningful manner, it is more likely that they will consider the outcome to be legitimate (Tyler, 2011). This claim renders the expansion of direct democratic procedures particularly appealing as a potential remedy for the alleged contemporary crisis of representative democracy. While turnout levels are rapidly declining (Gray \& Caul, 2000; Dassonneville \& Hooghe, forthcoming), political parties are losing members (Dalton \& Wattenberg, 2002; Mair \& van Biezen, 2001; van Biezen, Mair, \& Poguntke, 2012; Whiteley, 2011) and citizens become increasingly skeptical towards democratic processes and its institutions (Kaase \& Newton, 1995; Klingemann, 1999; Newton \& Norris, 2000), proponents of direct democracy argue that increased direct engagement of citizens can contribute to maintain and enhance perceptions of legitimacy and strengthen citizens' linkage with the state (Cain, Dalton, \& Scarrow, 2003). Instead of electing public officials, referenda and other similar initiatives allow citizens a direct instrument to decide on how their country should be run.

In previous studies it is suggested that citizens who live in direct democracies believe more strongly that government is responsive to their demands (Bowler and Donovan 2002; Hero and Tolbert 2004; Mendelsohn and Cutler 2000). Smith and Tolbert (2004) show that the availability of direct democracy initiatives is associated with higher levels of political knowledge, and they assume that citizens put more effort in getting themselves informed if they live in a system where they are asked to be involved in the decision-making process. Some of the research suggests that the availability of direct democracy is associated with higher levels of political knowledge, interest (Smith 2002) and civic engagement (Smith and Tolbert 2004; Tolbert, McNeal, and Smith 2003). The assumption is that when citizens know it is likely they will have to express their opinions on salient 
political issues, they will experience this as an incentive to obtain information on these issues. Therefore, strengthening the opportunities for direct democracy is often considered to be a key element of democratic innovation, as it is stated that opening up the possibility to decide for oneself should restore or strengthen democratic legitimacy (Geißel \& Newton, 2012).

However, even by proponents of direct democracy, direct democratic instruments are widely considered as a supplement to representative democracy, rather than a replacement (Frey, 1994). Introducing direct democracy would always imply that referenda, in some way or another, will be combined with the indirect, institutionalized and non-institutionalized instruments of representative democracy. Therefore, the question how these new channels of citizen engagement would affect the existing channels of political participation in the representative system is crucial. As no author sees direct democracy as a stand-alone instrument that would solve the entire complex interaction between citizens and the state, its effects should not be investigated in an isolated manner. Rather, it is important to investigate what effect direct democracy has on the whole array of institutionalized and non-institutionalized instruments citizens have at their disposal to get their voice heard, and that is exactly the goal of the current paper. If direct democracy would be associated with, e.g., a lower level of willingness to become engaged in electoral politics, this would counter-act much of the democratic gain associated with the referenda themselves. This study therefore focuses on the potential effects of direct democracy on participatory equality in different forms of political participation. If direct democracy would have a negative spill-over effect on other, well-established forms of political participation, this might eliminate any democratic effects the direct procedure itself might have. Participatory equality, which represents a basic goal of democratic systems, is assumed to be reached when in making collective decisions, the interests of all citizens are equally taken into account (Dahl, 1989, 1996; Marien, Hooghe, \& Quintelier, 2010). Citizens do not only communicate their interests, preferences and needs through political participation, they also use the institutionalized and non-institutionalized channels of participation to pressure public officials so that those interests are taken into account. As citizens' interests and preferences differ, the equal consideration of all interests would seem to require equal participatory input. The quality of a democratic system therefore depends not only on the sheer volume of political participation but also on its distribution across the population. Previous research has shown that political participation is stratified along the measures of socioeconomic status, and most notably along levels of income and education (Berinsky, 2002; Stolle \& Hooghe, 2011; 
Verba, Nie, \& Kim, 1978; Verba, Schlozman, \& Brady, 1995). This paper therefore aims to answer the question whether the existence, regulations, and use of national referendums and initiatives affects the stratification of political participation along the measures of socioeconomic status.

The current literature yields mixed results on the relationship between levels of political participation and direct democracy. While some scholars find that voter turnout is higher in systems where direct democratic rights are available (Tolbert, Grummel \& Smith, 2001; Tolbert, McNeal $\&$ Smith, 2003; Tolbert \& Smith, 2005), others find that direct democracy has a negative effect (Freitag \& Stadelmann-Steffen, 2010) or no effect on electoral turnout (Fatke, 2015) and virtually no effect on non-institutionalized forms of political participation (Dalton \& Weldon 2013). Peters (2016) argues that these inconclusive findings might stem from the fact that different institutions of direct democracy have different effects on political participation. Initiative referendums and agenda initiatives function in a complementary way to institutions of representative democracy and therefore they might boost political participation. However, other institutions of direct democracy such as recalls and constitutional and legislative referendums fulfill tasks that are traditionally accomplished by institutions of representative democracy. Therefore, these specific institutions of direct democracy compete with the institutions of representative democracy and function as an alternative channel in the decision making process. As a consequence, the extensive availability of recalls and constitutional and legislative referendums is argued to depress electoral participation.

In summary, it can be stated that direct democracy does not necessarily lead to more political participation. Moreover, what we also know from the Swiss case is that direct democratic instruments are not used by everybody in the same manner, particularly when turnout is low (Linder, 1994). Fatke (2015), on the other hand, suggests that direct democracy does neither increases nor decrease social bias in the Swiss electorate. A limitation to this study is that it only tests the moderating effect of direct democracy on the relationship between socio-economic status and electoral participation. Less, however, is known about the effect of direct democracy on the stratification of political participation more generally. Two competing theoretically informed scenarios are possible to explain this relation.

First, it could be assumed that direct democracy creates greater equality in political participation. Advocates of participatory democracy expect that participation has a socializing and empowering effect on citizens (Barber, 1984; Pateman, 1970, 2012). It is argued that by participating regularly, 
citizens become psychologically more engaged and this should hold for all citizens, independent of their socioeconomic status. Dalton and Weldon (2013) argue that referenda could function as an ideal training ground for political participation more broadly defined, as typically a referendum boils down to a very easy yes/no option. Theoretically, this should make participation easier than taking part in e.g. parliamentary elections, where voters are confronted with a myriad of issues, parties and candidates. Offering this kind of low-intensity act, therefore should lead to a positive spill-over effect on other forms of participation: "because of their low involvement costs, referendums can act as a gateway to broader, more intensive types of political participation" (Dalton \& Weldon, 2013, p. 53). If referenda are considered as an 'easy' form of participation, they should offer more opportunities to especially the least sophisticated, and therefore the expectation is that they contribute to political equality. Once the lower-educated have the experience that they can cast a meaningful vote in a referendum, it is more likely that they will also take the next step to fully engage in institutionalized and non-institutionalized participation.

An opposing line of the literature, however, expects exactly the opposite spill-over effect. While direct democratic instruments represent more opportunities for citizens to voice their interests and preferences, they also require that citizens make additional decisions which they would not have to make in a purely representative system. For every referendum, this implies that they need to inform themselves about the issues at stake and to obtain additional cues in order to take an informed decision (Donovan \& Karp, 2006). Direct democratic initiatives and referendums thus create additional cognitive costs for citizens and they render the system more complex for its citizens. Especially for the citizens with the lowest levels of political sophistication, this might imply an additional barrier for effective participation in general. Those citizens could hence be expected to refrain from political participation all together: They would neither engage in the direct democratic initiatives and referendums nor in the institutionalized and non-institutionalized ways that are characteristic of today's representative democracies. Given the fact that especially noninstitutionalized forms of participation require more effort, the literature on the "participation paradox', would allow us to assume that these acts will be the first ones to suffer from the attention that is being devoted to forms of direct democracy. Previous research has shown that the emergence of new, additional forms of political participation has led to more, rather than less distortion of political participation along the lines of education (Marien et al., 2010; Stolle \& Hooghe, 2011). Also, existing studies show that direct democracy fosters voter fatigue among citizens (Bowler, 
Donovan, \& Happ, 1992). The basic argument here is that citizens are not willing or able to be routinely involved in all kinds of political decision-making. If they experience that the demands placed on their cognitive resources or on their spare time become too intensive, the easiest solution is simply to refrain from all of these institutionalized and non-institutionalized political acts. This line of the research therefore leads to the hypothesis that a proliferation of participation opportunities would lead to a reduced willingness to participate, especially among the population groups with lower levels of political sophistication. These two lines of the literature thus lead to opposite expectations on the spill-over effect of direct democracy on other forms of participation. While quite some of the earlier studies on this topic have been limited to one country, or a limited number of countries, in this paper we will investigate the occurrence of these spill-over effects for a vast array of European countries, that have participated in the European Social Survey.

\section{Data, Measurement and Method}

To test the moderating effect of direct democracy on the relationship between socioeconomic status and political participation we rely on cross-national individual level data from the fifth round of the European Social Survey (ESS Round 5: European Social Survey Round 5 Data, 2010). These population figures are combined with information from the Index of Power Dispersion in Direct Democracy from the Diffusion of Power in 61 Democracies dataset (Vatter \& Bernauer, 2015).

This study presents a synchronic comparison of the effect of socioeconomic status on political participation in 23 European states in 2010. The European Social Survey has been chosen as data source, because the data is comparable and because the ESS is respected due to its high standards concerning the survey design and the data collection (Lynn, 2003). We have selected the fifth round, because it contains the broadest range of data on political participation, as the question on party membership was no longer included in subsequent rounds of ESS. The fifth round of the ESS which was administered in 2010 contains cross-sectional samples from 28 countries.

For 24 of those countries, we also have information available on the availability of direct democracy for its citizens: Belgium, Bulgaria, Switzerland, Czech Republic, Germany, Denmark, Estonia, Spain, Finland, France, the United Kingdom, Greece, Croatia, Hungary, Ireland, Israel, Lithuania, the Netherlands, Norway, Poland, Portugal, Sweden, Slovenia, Slovakia. The units of 
analysis are individuals, which were interviewed face-to-face. In total 46,849 respondents participated in the survey.

The ESS Round 5 contains information about eight different forms of political participation. The respondents were asked whether they participated in these following forms of action during the last 12 months: contacting a politician or other government official, working in a political party or political action group, displaying political views by wearing a badge or sticker, signing a petition, taking part in lawful public demonstrations and boycotting certain products. Moreover, the respondents were asked whether they are a member of a political party and whether they had voted in the last national election. The eight variables resulting from these questions were recoded as dichotomous variables that take on 0 for "No" and 1 for "Yes". Respondents who did not give any answer, opted for "Don't know" or were not eligible to vote in the previous national elections were excluded from the analysis. The frequencies with which respondents indicated that they had participated in a particular form of political participation are presented in Table 1.

\section{Table 1: Frequencies of Different Participation Forms}

\begin{tabular}{lr}
\hline Activity & per cent \\
\hline Voting & 76.7 \\
Signing a petition & 19.8 \\
Boycotting certain products & 14.0 \\
Contacting a politician & 12.9 \\
Wearing or displaying a campaign badge/sticker & 6.9 \\
Demonstrating & 5.8 \\
Party member & 4.2 \\
Working in a political party or action group & 3.3 \\
\hline
\end{tabular}

Note: Data weighted with design weights and population weights.

Source: ESS Round 5 (2010).

Looking at Table 1, one notes that voting represents by far the most widely spread form of political participation, followed by signing petitions and boycotting specific products. On the other hand, being a party member, working in a political party and action group do not seem to be very widespread as forms of political participation among European respondents.

In line with the existing literature, going back to the participation typology created by Barnes and Kaase (1979), we distinguish between three forms of political participation: voting, 
institutionalised and non-institutionalised forms of political participation (Marien et al., 2010; Stolle et al., 2011). First, voting is regarded as a single item, as just because of its sheer volume this act would fully determine any other factor. Working for a political party or action group and being a member of a political party are considered as acts of institutionalised political participation that are related to the electoral process, whereas signing a petition, taking part in a lawful demonstration are boycotting certain products represent non-institutionalised forms of political participation. Wearing a badge or sticker as well as contacting a politician are excluded from the analysis, because they cannot clearly be identified as institutional or non-institutional acts ${ }^{1}$. As the distribution of participation acts is not normal, both variables were dichotomized (did not participate in any act vs participated in at least one of these acts). Hence, all three participation variables are binary.

The independent variable of interest is socioeconomic status which is measured based on two indicators from the ESS (2010): level of education and household income. The level of education was recoded into three broad categories, distinguishing between 1) those who have no formal or only primary education, 2) those who obtained secondary education and 3) all those with tertiary education. Looking at an individual's income represents another straightforward way to measure socio-economic status. This is done by including the item that captures the respondents' total available household income ${ }^{2}$.

Direct democracy which serves as moderating variable is measured with the Index of Power Dispersion in Direct Democracy (Vatter \& Bernauer, 2015) that distinguishes between forms of direct democracy that concentrate power and forms of direct democracy that disperse power. The index was developed in an effort to expand on the rather rudimentary dichotomy Lijphart (2012) uses to investigate the role of direct democracy in distinguishing between various styles of democracy. This index has been chosen because it considers not only the existence but also the regulations and use of national referendums and initiatives. In the index, countries are awarded points according to two criteria: First, if they have legislation on direct democratic instruments. Second, countries receive additional points if these direct democratic instruments are actually used. The index therefore does not just express what is the legal status of a referendum, but also how often it is being used. This implies a high score for a country like Switzerland with its strong tradition of referenda and Lithuania, where twelve nation-wide referenda were held since 
independence in 1990, and a zero score for Belgium, Germany or the United Kingdom, countries that have no provision for a national referendum whatsoever.

Finally, we control on the individual level for sex, the age of the respondents in 2010 and for their level of political interest, as high levels of political interest increase the probability to become politically engaged (Neundorf, Smets, \& García-Albacete, 2013; Verba et al., 1995). Also, we include a categorical variable to account for respondents' employment status. This variable is recoded so that white collar workers form the reference category while the other categories are dummy coded. These dummies represent 1) blue collar workers, 2) unemployed respondents and 3) others. ${ }^{3}$ The differentiation between white collar and blue collar jobs was made based on the ISCO88 codes (jobs with codes $0,1,2,3,4$ and 5 are considered as white collar jobs). On the country level we control for a country's democratic history, because levels of political participation are lower still lower in Eastern European countries whose democratic transition is rather recent (Hooghe \& Quintelier, 2013). To this end, a dummy is introduced that distinguishes established and more recent European democracies.

All in all, after removing those cases that contain missing information, we obtained a sample of 40,329 respondents who live in 23 European countries. We account for this nested structure by estimating logistic multilevel models.

\section{Results}

Our analysis is based on the assumption that the indicators of socio-economic status affect the probability respondents will become engaged in political participation and that these effects differ across the different countries. In Table 2 we test the first of the two assumptions, and we do so separately for every form of political participation we distinguished. First we estimate null-models, showing there is quite some country-level correlation, ranging from four per cent for institutionalized participation (Model III), over nine per cent for voting (Model I), to 16 per cent for non-institutionalised participation (Model V).

If we subsequently add the independent variables, the results show that the level of education represents a strong determinant of stratification for all three types of political participation. Tertiary 
education (as compared to secondary education) is positively related to all three forms of political participation. Additionally, for citizens with primary education the probability to engage in noninstitutionalised political participation is significantly lower than for citizens with secondary education (Model VI). Income increases the probability to vote (Model II) and the probability to become involved in non-institutionalised political participation (Model VI). However, it does not affect the probability to engage in institutionalised political participation (Model IV). In sum, our findings support the already existing literature that states that citizens' socioeconomic status represents an important source of stratification in political participation. This seems to be particularly true for voting and for non-institutionalized engagement.

When we move to the country-level variables in Table 2, we can first observe that noninstitutionalised participation is lower in countries that made their democratic transition following the fall of the authoritarian regimes in Eastern Europe. For the two other forms of participation we do not find any significant differences with the more established democracies. The presence of direct democracy, furthermore, also does not seem to have an effect on institutionalised an noninstitutionalised participation, but we do observe a negative effect on the level of voting. This might serve as a first indication for a form of voter fatigue.

So far, we have only tested the assumption on which our argumentation is built, namely that socioeconomic status stratifies political participation. However, based on our reasoning, we are actually interested in whether the effects of socio-economic status on participation change depending on the degree of direct democracy. In order to test this, we allow the indicators of socioeconomic status vary - one by one - across the 23 counties and we introduce cross-level interactions in order to investigate whether the degree of direct democracy can explain the changes in these effects.

We start in Table 3 with the analysis of voting. While the effects of tertiary education and income voting vary across the countries, direct democracy cannot explain this variation, as all cross-level interactions are insignificant. Also, with respect to the effect of socio-economic status on institutionalised political participation (Table 4, Models I-III), the degree of direct democracy does not explain the variance that we found across the countries. However, the degree of direct democracy does moderate the effects of primary education, tertiary education and income on the probability to engage in non-institutionalised forms of political participation. Model IV shows that 
the negative effect of primary education on non-institutionalized participation that was shown in Model VI, Table 2 is enforced in countries with a high degree of direct democracy. Also the positive effect of tertiary education (compared to secondary education) becomes stronger, the higher the degree of direct democracy. Both findings support the reasoning that in systems with an extensive availability and use of direct democratic instruments, participatory inequality is higher. Also Model VI is in line with this claim: The positive effect of income on non-institutionalized political participation is enhanced in countries that are characterized by a high degree of direct democracy ${ }^{4}$. 
Table 2. The effect of direct democracy on the probability to participate politically

\begin{tabular}{|c|c|c|c|c|c|c|}
\hline & \multicolumn{2}{|c|}{ Voting } & \multicolumn{2}{|c|}{$\begin{array}{l}\text { Institutionalized } \\
\text { participation }\end{array}$} & \multicolumn{2}{|c|}{$\begin{array}{c}\text { Non-institutionalized } \\
\text { participation }\end{array}$} \\
\hline & Model I & Model II & Model III & Model IV & Model V & Model VI \\
\hline Intercept & $3.651 * * *$ & $4.851 * * *$ & $0.061 * * *$ & $0.033 * * *$ & $0.360 * * *$ & $0.674 * *$ \\
\hline \multicolumn{7}{|l|}{ Individual-level variables } \\
\hline Male & & $0.841 * * *$ & & $1.438 * * *$ & & $0.853 * * *$ \\
\hline Age & & 1.000 & & 1.000 & & 1.000 \\
\hline Political interest & & $1.919 * * *$ & & $2.373 * * *$ & & $1.528 * * *$ \\
\hline \multicolumn{7}{|l|}{$\begin{array}{l}\text { Level of education (ref. } \\
\text { secondary education) }\end{array}$} \\
\hline Primary education & & 0.961 & & 1.074 & & $0.623 * * *$ \\
\hline Tertiary education & & $1.318 * * *$ & & $1.236 * * *$ & & $1.423 * * *$ \\
\hline Income & & $1.047 * * *$ & & 1.014 & & $1.044 * * *$ \\
\hline \multicolumn{7}{|l|}{$\begin{array}{l}\text { Employment (ref. white } \\
\text { collar) }\end{array}$} \\
\hline Blue collar & & $0.833^{* * *}$ & & 0.997 & & $0.780 * * *$ \\
\hline Unemployed & & $0.563 * * *$ & & 0.829 & & 0.999 \\
\hline Other & & $1.107 * *$ & & 1.063 & & $0.771 * * *$ \\
\hline \multicolumn{7}{|l|}{ Country-level variables } \\
\hline Post-communist country & & 0.733 & & 0.899 & & $0.378 * * *$ \\
\hline Direct democracy & & $0.933 * *$ & & 0.995 & & 0.975 \\
\hline Individual-level variance & 3.290 & 2.827 & 3.290 & 2.593 & 3.290 & 2.951 \\
\hline Country-level variance & 0.305 & 0.133 & 0.152 & 0.117 & 0.618 & 0.266 \\
\hline Intra-class correlation & 0.085 & 0.045 & 0.044 & 0.043 & 0.158 & 0.083 \\
\hline Deviance & 33,562 & 30,928 & 15,652 & 14,158 & 38,359 & 35,881 \\
\hline McKelvey \& Zavoina's R ${ }^{2}$ & & 0.219 & & 0.215 & & 0.178 \\
\hline $\mathrm{N}_{\text {individuals }}$ & 32,438 & 32,438 & 34,655 & 34,655 & 34,655 & 34,655 \\
\hline $\mathrm{N}_{\text {countries }}$ & 23 & 23 & 23 & 23 & 23 & 23 \\
\hline
\end{tabular}


Table 3. The effect of socio-economic status on the probability to vote moderated by direct democracy

\begin{tabular}{|c|c|c|c|}
\hline & \multicolumn{3}{|c|}{ Vote } \\
\hline & Model I & Model II & Model III \\
\hline Intercept & $4.969 * * *$ & $4.336 * * *$ & $4.442 * * *$ \\
\hline Individual-level variables & & & \\
\hline Primary education (ref. secondary education) & $0.770 * * *$ & & \\
\hline Tertiary education (ref. secondary education) & & $1.331 * *$ & \\
\hline Income & & & $1.048 * * *$ \\
\hline Country-level variables & & & \\
\hline Direct democracy & $0.932 * *$ & $0.935^{* *}$ & $0.935 * *$ \\
\hline Cross-level interactions & & & \\
\hline Direct democracy*Primary education & 0.998 & & \\
\hline Direct democracy*Tertiary education & & 0.987 & \\
\hline Direct democracy*Income & & & 0.996 \\
\hline Variance components & & & \\
\hline Individual-level: within countries & 2.670 & 2.825 & 2.825 \\
\hline Country-level: intercept variance & 0.127 & 0.149 & 0.129 \\
\hline Slope variance of primary education & 0.069 & & \\
\hline Slope variance of tertiary education & & 0.131 & \\
\hline Slope variance of income & & & 0.002 \\
\hline Slope variance of unemployed & & & \\
\hline Intercept-slope covariance & -0.007 & -0.067 & -0.006 \\
\hline Deviance & 30,237 & 30,874 & 30,873 \\
\hline McKelvey \& Zavoina's $\mathrm{R}^{2}$ & 0.216 & 0.167 & 0.177 \\
\hline $\mathrm{N}_{\text {individuals }}$ & 32,635 & 32,438 & 32,438 \\
\hline $\mathrm{N}_{\text {countries }}$ & 23 & 23 & 23 \\
\hline
\end{tabular}


Table 4. The effect of socio-economic status on the probability to become active in institutionalized and non-institutionalized political participation moderated by direct democracy

\begin{tabular}{|c|c|c|c|c|c|c|}
\hline & \multicolumn{3}{|c|}{ Institutionalized political participation } & \multicolumn{3}{|c|}{ Non-institutionalized political participation } \\
\hline & Model I & Model II & Model III & Model IV & Model V & Model VI \\
\hline Intercept & $0.051 * * *$ & $0.045 * * *$ & $0.052 * * *$ & $0.654 * *$ & $0.612 * *$ & $0.615 * *$ \\
\hline Individual-level variables & & & & & & \\
\hline Primary education (ref. secondary education) & 0.996 & & & $0.594 * * *$ & & \\
\hline Tertiary education (ref. secondary education) & & $1.281 * *$ & & & $1.468 * * *$ & \\
\hline Income & & & 1.021 & & & $1.051 * * *$ \\
\hline Country-level variables & & & & & & \\
\hline Direct democracy & 1.001 & 0.992 & 0.996 & 0.979 & 0.960 & 0.965 \\
\hline Cross-level interactions & & & & & & \\
\hline Direct democracy*Primary education & 0.959 & & & $0.961 *$ & & \\
\hline Direct democracy*Tertiary education & & 0.999 & & & $1.036^{*}$ & \\
\hline Direct democracy*Income & & & 1.002 & & & $1.007 * *$ \\
\hline Variance components & & & & & & \\
\hline Individual-level: within countries & 2.580 & 2.593 & 2.585 & 2.943 & 2.947 & 2.944 \\
\hline Country-level: intercept variance & 0.123 & 0.152 & 0.117 & 0.258 & 0.343 & 0.283 \\
\hline Slope variance of primary education & 0.077 & & & 0.036 & & \\
\hline Slope variance of tertiary education & & 0.056 & & & 0.050 & \\
\hline Slope variance of income & & & 0.002 & & & 0.001 \\
\hline Intercept-slope covariance & -0.023 & -0.066 & 0.001 & 0.013 & -0.108 & -0.010 \\
\hline Deviance & 14,189 & 14,146 & 14,194 & 35,855 & 35,830 & 35,832 \\
\hline McKelvey \& Zavoina's $\mathrm{R}^{2}$ & 0.213 & 0.207 & 0.218 & 0.174 & 0.156 & 0.159 \\
\hline $\mathrm{N}_{\text {individuals }}$ & 34,760 & 34,655 & 34,760 & 34,655 & 34,655 & 34,655 \\
\hline $\mathrm{N}_{\text {countries }}$ & 23 & 23 & 23 & 23 & 23 & 23 \\
\hline
\end{tabular}

Note: The dependent variable in Models I-III is the probability to participate in institutionalized political participation and in Models IV-VI, the dependent variable is the probability to participate in non-institutionalized political participation: probability of participation in no activity (=0), probability to participate in at least one activity $(=1)$. Entries are odds ratios of a multilevel logistic regression. In every model we control for the gender, age, political interest and employment on the individual level and for countries' communist past on the second level. All models are rescaled to same scale as the intercept-only model. Sign.:* $\mathrm{p}<0.05, * * \mathrm{p}<0.01, * * * \mathrm{p}<0.001$ 


\section{Discussion}

Despite the ever-increasing popularity of direct democratic instruments, little is known about how these institutions affect the institutions of representative democracy. With this article we shed light on this interplay by investigating the moderating effect of direct democracy on the relationship between socio-economic status and political participation. We have discussed two possible scenarios. For citizens with a low socio-economic status that are less likely to become politically involved direct democracy could on the one hand function as "gateway" to other types of political participation. On the other hand, however, it could also render the system more complex and lead to a fatigue that is particularly prominent among citizens with a low socio-economic status. While the first scenario would lead to more participatory equality, the latter will further undermine it. The results of our analysis support the second scenario: In systems with an extensive availability and use of direct democratic instruments, the level of education and income appear to be more important as predictors of non-institutionalized political participation than in countries where direct democratic instruments are less prominent. Not only is participation in referenda and initiatives distorted along the lines of education (Kriesi, 2008; Linder, 1994), these inequalities also seem to spill-over into other forms of non-institutionalized political participation. Apparently, socioeconomically disadvantaged citizens who refrain from using the additional channels that are provided in direct democracy systems, also abstain from participation through other channels offered by the representative system. It seems thus conceivable that in systems with a high degree of direct democracy, the system's complexity induces a general participatory fatigue among this strata of the population. However, this has been observed only for non-institutionalized forms of political participation. With respect to voting and institutionalized participation, the availability of direct democratic procedures does not have a differentiated effect on the various population groups. Nevertheless, it should be noted, that while there might be solid normative arguments in favour of direct democracy, the downside might be that it dampens the enthusiasm of specific groups of the population to participate in forms of non-institutionalized political participation.

Obviously the goal of the current article was not to challenge the hypothesis that direct democracy leads to a 'kinder, gentler' form of democracy, as we did not analyze the effect of direct democracy on various forms of democratic attitudes. Following earlier analysis, we can indeed expect that there is an effect in this regard and we do not want to challenge this assumption. Given the current 
concern about the (lack of) democratic legitimacy in liberal democracies, this does remain a very important consideration in the debate. What we did show, however, is that there might also be a drawback to this positive effect of direct democracy, as apparently the lower educated do not use the political participation repertoire as intensively as the highly educated in a country where they are routinely asked to provide input by means of a referendum or an initiative. Possibly, more complex systems could counteract this fatigue among the socioeconomically disadvantaged strata of society by providing widely accessible information shortcuts (Lupia, 1994).

It has to be noted also that in our sample, the countries that have direct democratic procedures, add these to the electoral procedures that are available. The result is that the citizens of these countries have a wide array of participation opportunities. If, theoretically, direct democracy would actually replace some forms of representative democracy, the total number of participation opportunities would not rise, so it be worthwhile to investigate whether in such a context, we would observe similar democratic fatigue effects. It should also be clear that our assessment of the effects of direct democracy is dependent on current practices with regard to frequency and mobilization patterns. One could indeed imagine different forms of direct democracy, with a larger role of mobilization structures and initiatives. Here too, however, we have to noted that we are limited by the data that are currently available. As a further limitation, it has to be noted that we only had access to crosssectional data, and in the future more longitudinal data, especially from political systems with a strong experience in direct democracy, could help us to established patterns of causality in a more convincing manner.

It falls outside the scope of the current article to investigate why exactly direct democracy has this effect. When we consider Switzerland as an outlier (and in the case of the prevalence of direct democracy, there is every reason to do so), we can observe that direct democracy does not diminish in a significant manner the participation level of lowly educated groups within the population. Rather, the highly educated seem to be more eager to actually use all the opportunities that are on offer to express their opinion, and this by itself is sufficient to create a larger gap within the population. Basically, this means that especially the higher educated also use the opportunities created by systems of direct democracy, and they also seem to be able to exploit these opportunities. This finding therefore is perfectly in line with the assumptions of the participation model developed by Verba, Schlozman and Brady (1995). The more opportunities there are for participation, the 
easier it will be for citizens with a high level of political resources to use those opportunities to make sure their interests are being taken into account by the political system. Citizens with fewer skills and resources, on the other hand, are much less apt to use all these opportunities, thus indeed leading to a stronger participation paradox. In the quest for a better functioning democracy, apparently a trade-off between opportunities and equality is an element that thus far has been largely neglected in the literature. 


\section{References}

Barber, B. (1984). Strong Democracy: Participatory politics for a new age. Berkeley: University of California Press.

Barnes, S. \& Kaase, M. (1979). Political Action. Beverly Hills: Sage.

Berinsky, A. J. (2002). Silent Voices: Social Welfare Policy Opinions and Political Equality in America. American Journal of Political Science, 46(2), 276-287.

Bowler, S., \& Donovan, T. (2002). Democracy, Institutions and Attitudes about Citizen Influence on Government.British Journal of Political Science, 32(2), 371-390.

Bowler, S., Donovan, T., \& Happ, T. (1992). Ballot Propositions and Information Costs: Direct Democracy and the Fatigued Voter. Western Political Quarterly, 45(2), 559-568.

Brady, H. E., Verba, S., \& Schlozman, K. L. (1995). Beyond SES: A Resource Model of Political Participation. American Political Science Review, 89(2), 271-294.

Budge, I. (1996). The New Challenge of Direct Democracy. Cambridge: Polity Press.

Cain, B. E., Dalton, R. J., \& Scarrow, S. E. (2003). Democracy transformed? The Expanding Political Opportunities in Advanced Industrial Democracies. Oxford: Oxford University Press.

Dahl, R. A. (1989). Democracy and its Critics. New Haven: Yale University Press.

Dahl, R. A. (1996). Equality versus Inequality. PS: Political Science and Politics, 29(4), 639648.

Dalton, R. J., \& Wattenberg, M. P. (Eds.). (2002). Parties without Partisans: Political change in advanced industrial democracies. Oxford: Oxford University Press.

Dalton, R. J., \& Weldon, S. (2013). Is Direct Democracy a Kinder and Gentler Democracy? Taiwan Journal of Democracy, 9, 39-62.

Dalton, R. J., \& Welzel, C. (Eds.). (2015). The Civic Culture Transformed: From Allegiant to Assertive Citizens. Cambridge: Cambridge University Press.

Dassonneville, R., \& Hooghe, M. (forthcoming). Voter Turnout Decline and Stratification. Quasi-Experimental and Comparative Evidence of a Growing Educational Gap. Politics, in press. Doi: 10.1177/0263395716674370

Donovan, T., \& Karp, J. A. (2006). Popular Support for Direct Democracy. Party Politics, 12(5), $671-688$.

Dyck, J. J. (2009). Initiated Distrust: Direct Democracy and Trust in Government. American 
Politics Research, 37(4), 539-568.

ESS Round 5: European Social Survey Round 5 Data. (2010). Data file edition 3.2. Norwegian Social Science Data Services, Norway - Data Archive and distributor of ESS data.

Fatke, M. (2015). Participation and Political Equality in Direct Democracy: Educative Effect or Social Bias. Swiss Political Science Review, 22(1), 99-118.

Freitag, M., \& Ackermann, K. (2016). Direct Democracy and Institutional Trust: Relationships and Differences across Personality Traits. Political Psychology, 37(5), 707-723.

Freitag, M., \& Stadelmann-Steffen, I. (2010). Stumbling Block or Stepping Stone? The Influence of Direct Democracy on Individual Participation in Parliamentary Elections. Electoral Studies, 29, 472-483.

Frey, B. S. (1994). Direct Democracy: Politico-Economic Lessons from Swiss Experience. American Economic Review, 84(2), 338-342.

Geißel, B., \& Newton, K. (Eds.). (2012). Evaluating Democratic Innovations. Curing the democratic malaise? Abingdon: Routledge.

Gray, M., \& Caul, M. (2000). Declining Voter Turnout in Advanced Industrial Democracies, 1950 to 1997: The Effects of Declining Group Mobilization. Comparative Political Studies, 33(9), 1091-1122.

Grönlund, K., Herne, K., \& Setälä, M. (2015). Does Enclave Deliberation Polarize Opinions? Political Behavior, 37(4), 995-1020.

Hero, R., \& Tolbert, C. (2004). Minority Voices and Citizen Attitudes about Government Responsiveness in the American States: Do Social and Institutional Context Matter? British Journal of Political Science, 34(1), 109-123.

Hooghe, M. (1999). The Rebuke of Thersites. Deliberative democracy under conditions of inequality. Acta Politica, 34(4), 287-301.

Hooghe, M., \& Quintelier, E. (2013). Political Participation in European Countries: The effect of authoritarian rule, corruption, lack of good governance and economic downturn. Comparative European Politics, 12(2), 209-232.

Jackman, S. (1999). Correcting surveys for non-response and measurement error using auxiliary information. Electoral Studies, 18(1), 7-27.

Kaase, M., \& Newton, K. (1995). Beliefs in government. Oxford: Oxford University Press. Klingemann, H.-D. (1999). Mapping Political Support in the 1990s: A Global Analysis. In P. 
Norris (Ed.), Critical citizens: Global support for democratic governance (pp. 31-56). Oxford: Oxford University Press.

Kriesi, H. (2004). Political context and opportunity. In D. Snow, S. Soule \& H. Kriesi (Eds.), The Blackwell Companion to Social Movements (pp. 67-90). Oxford: Blackwell Publishing.

Kriesi, H. (2008). Direct Democratic Choice. The Swiss Experience. Lanham: Lexington Books. Lijphart, A. (2012). Patterns of Democracy: Government Forms and Performance in Thirty-Six Countries, 2nd updated edition. New Haven: Yale University Press.

Linder, W. (1994). Swiss Democracy: Possible Solutions to Conflict in Multicultural Societies. New York: St. Martin's Press.

Lupia, A. (1994). Shortcuts Versus Encyclopedias: Information and Voting Behavior in California Insurance Reform Elections. American Political Science Review, 88(1), 63-76.

Mair, P., \& van Biezen, I. (2001). Party Membership in Twenty European Democracies, 19802000. Party Politics, 7(1), 5-21.

Marien, S., Hooghe, M., \& Quintelier, E. (2010). Inequalities in Non-institutionalised Forms of Political Participation: A Multi-level Analysis of 25 countries. Political Studies, 58(1), 187213.

Mendelsohn, M., \& Cutler, F. (2000). The Effect of Referendums on Democratic Citizens: Information, Politicization, Efficacy and Tolerance. British Journal of Political Science, 30(4), 669-698.

Neundorf, A., Smets, K., \& García-Albacete, G. M. (2013). Homemade Citizens: The Development of Political Interest During Adolescence and Young Adulthood. Acta Politica, 48(1), 92-116.

Newton, K., \& Norris, P. (2000). Conficence in Public Institutions: Faith, Culture or Performance? In S. J. Pharr \& R. D. Putnam (Eds.), Disaffected Democracies: What's troubling the trilateral democracies? (pp. 52-74). Princeton: Princeton University Press.

Nie, N., Junn, J., \& Stehlik-Barry, K. (1996). Education and Democratic Citizenship in America. Chicago: University of Chicago Press.

Norris, P. (2002). Democratic Phoenix: Reinventing Political Activism. New York: Cambridge University Press.

Pateman, C. (1970). Participation and Democratic Theory. Cambridge: Cambridge University Press. 
Pateman, C. (2012). Participatory Democracy Revisited. Perspectives on Politics, 10(1), 7-19. Peters, Y. (2016). Zero-Sum Democracy? The Effects of Direct Democracy on Representative Participation. Political Studies, 64(3), 593-613.

Qvortrup, M. (Ed.). (2014). Referendums around the World: The Continued Growth of Direct Democracy. Basingstoke: Palgrave.

Roemer, J. E. (2000). Equality of Opportunity. Cambridge: Harvard University Press.

Schlozman, K. L., Verba, S. \& Brady, H. E. (2012). The Unheavenly Chorus: Unequal Political Voice and the Broken Promise of American Democracy. Princeton: Princeton University Press.

Smith, M. (2002). Ballot Initiatives and the Democratic Citizen. The Journal of Politics, 64(3), 982-903.

Smith, D. A, \& Tolbert, C. J. (2004). Educated by Initiative: The Effects of Direct Democracy on Citizens and Political Organizations in the American. Ann Arbor: University of Michigan Press.

Stolle, D., \& Hooghe, M. (2011). Shifting Inequalities. European Societies, 13(1), 119-142.

Tarrow, S. G. (1998). Power in Movement: Social Movements and Contentious Politics. Cambridge: Cambridge University Press.

Tolbert, C. J., Grummel, J. A., \& Smith, D. A. (2001). The Effects of Ballot Initiatives on Voter Turnout in the American States. American Politics Research, 29(6), 625-648.

Tolbert, C. J., McNeal, R., \& Smith, D. A. (2003). Enhancing Civic Engagement: The Effect of Direct Democracy on Political Participation and Knowledge. State Politics \& Policy Quarterly, 3(1), 23-41.

Tolbert, C. J., \& Smith, D. A. (2005). The Educative Effects of Ballot Initiatives on Voter Turnout. American Politics Research, 33(2), 283-309.

Tormey, S. (2015). The End of Representative Politics. Cambridge: Polity Press.

Tyler, T. (2011). Why People Cooperate. Princeton: Princeton University Press.

Van Biezen, I., Mair, P., \& Poguntke, T. (2012). Going, going, . . gone? The decline of party membership in contemporary Europe. European Journal of Political Research, 51(1), 2456.

Vatter, A., \& Bernauer, J. (2015). Diffusion of Power in 61 Democracies. Unpublished Dataset (Version 8th of June 2015). Institut für Politikwissenschaft, Universität Bern. 
Verba, S. (2003). Would the Dream of Political Equality turn out to be a Nightmare? Perspectives on Politics, 1(4), 663-679.

Verba, S., \& Nie, N. H. (1972). Participation in America. Political Democracy and Social Equality. Chicago: University of Chicago Press.

Verba, S., Nie, N. H., \& Kim, J. (1978). Participation and Political Equality: A Seven-Nation Comparison. Cambridge: Cambridge University Press.

Verba, S., Schlozman, K. L., \& Brady, H. (1995). Voice and Equality: Civic Voluntarism in American Politics. Cambridge: Harvard University Press.

Whiteley, P. F. (2011). Is the Party Over? The Decline of Party Activism and Membership across the Democratic World. Party Politics, 17(1), 21-44.

Young, I. M. (2001). Activist Challenges to Deliberative Democracy. Political Theory, 29(5), 670-690. 


\section{Appendix: Variables used in the analysis}

\begin{tabular}{|c|c|c|c|c|c|c|c|}
\hline Variable & Operationalization & $\mathbf{N}$ & Mean & $\begin{array}{l}\text { Std. } \\
\text { Dev. }\end{array}$ & Min. & Max. & $\begin{array}{l}\text { Missing } \\
\text { in \% }\end{array}$ \\
\hline \multicolumn{8}{|l|}{ Dependent variables } \\
\hline Voting & Voted in the last national elections: $1=$ Yes, $0=$ No & 41,009 & 0.76 & 0.42 & 0 & 1 & 8.26 \\
\hline $\begin{array}{l}\text { Institutionalized } \\
\text { participation }\end{array}$ & $\begin{array}{l}\text { Worked in a political party or action group in the last } 12 \text { month } \\
\text { and/or were a member of a political party: } 1=\text { Yes, } 0=\text { No }\end{array}$ & 44,498 & 0.06 & 0.23 & 0 & 1 & 0.45 \\
\hline $\begin{array}{l}\text { Non-institutionalized } \\
\text { participation }\end{array}$ & 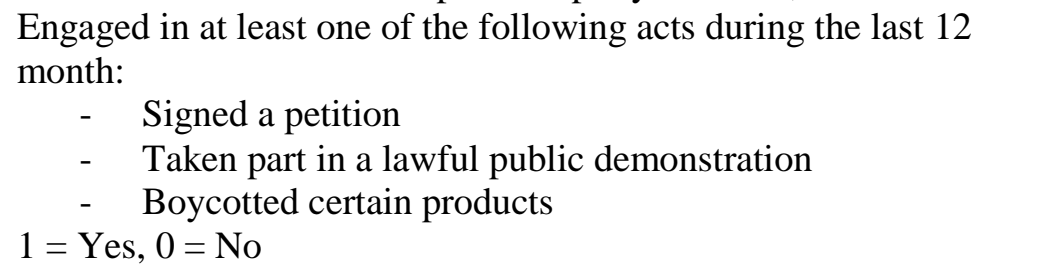 & 44,343 & 0.28 & 0.45 & 0 & 1 & 0.80 \\
\hline \multicolumn{8}{|c|}{ Individual level variables } \\
\hline Sex & $0=$ Female, $1=$ Male & 44,686 & 0.46 & 0.50 & 0 & 1 & 0.03 \\
\hline Age & Age in years & 44,568 & 47.77 & 18.75 & 14 & 100 & 0.29 \\
\hline \multicolumn{7}{|l|}{ Level of education } & 0.46 \\
\hline Primary education & $\begin{array}{l}\text { Less than lower secondary and lower secondary education: } \\
1=\text { Yes, } 0=\text { No }\end{array}$ & 44,449 & 0.30 & 0.46 & 0 & 1 & 0.56 \\
\hline $\begin{array}{l}\text { Secondary } \\
\text { education (Ref.) }\end{array}$ & $\begin{array}{l}\text { Upper secondary and advanced vocational education: } \\
1=\text { Yes, } 0=\text { No }\end{array}$ & 44,449 & 0.50 & 0.50 & 0 & 1 & 0.56 \\
\hline Tertiary education & $\begin{array}{l}\text { Lower and higher tertiary education: } \\
1=\text { Yes, } 0=\text { No }\end{array}$ & 44,449 & 0.20 & 0.40 & 0 & 1 & 0.56 \\
\hline Household income & $\begin{array}{l}\text { Household's total net income from all sources: } \\
1=1^{\text {st }} \text { decile, } 10=10^{\text {th }} \text { decile }\end{array}$ & 35,292 & 5.11 & 2.79 & 1 & 10 & 21.05 \\
\hline \multicolumn{8}{|l|}{ Employment status } \\
\hline $\begin{array}{l}\text { White collar } \\
\text { (Ref.) }\end{array}$ & $\begin{array}{l}\text { In paid work and with a job whose ISCO } 88 \text { code starts with } 0,1 \text {, } \\
2,3,4 \text { or } 5 \\
1=\text { Yes, } 0=\text { No }\end{array}$ & 44,569 & 0.32 & 0.47 & 0 & 1 & 0.29 \\
\hline Blue collar & $\begin{array}{l}\text { In paid work and with a job whose ISCO } 88 \text { code starts with } 6,7,8 \\
\text { or } 9 \\
1=\text { Yes, } 0=\text { No }\end{array}$ & 44,569 & 0.14 & 0.35 & 0 & 1 & 0.29 \\
\hline
\end{tabular}


Unemployed

Other

Country-level variables

Index of direct

democratic power

dispersion
Unemployed and actively looking for a job or unemployed, wanting a job but not actively looking for a job:

$1=$ Yes, $0=$ No

In education or permanently sick or disabled or retired or in community or military service or doing housework, looking after children or other

$1=$ Yes, $0=$ No

Vatter and Bernauer (2015) constructed the index of direct democratic power dispersion as an additive index. Points are awarded for both the existence and the use of direct democratic instruments.

The index accounts for the existence of direct democracy in the following way:

- one negative point is awarded for the existence of plebiscites

- one point is awarded for the existence of optional referendums and initiatives (if prescribed by the constitution)

- $\quad 0.5$ points are awarded for the existence of mandatory referendums

- $\quad 0.5$ points are awarded for each instrument of direct democracy when a quorum of participation (or approval) is required

- 1 point is awarded for each instrument of direct democracy when a qualified majority is required

Additionally points are awarded for the use of direct democracy:

- Negative points are awarded for the use of plebiscites

- Positive points are awarded for mandatory and facultative referendums and for initiatives

- In order to give countries with an extensive use of direct democratic instruments more weight in the index additional points are awarded depending on how often direct democratic instruments were used in the studied period: one positive (or, for plebiscites, negative) point is awarded for 1-10 votes, two points for 11-20 votes and three points for more than 20 votes

Democratic history Transition to democracy occurred less than 20 years ago (in 2010): $1=$ Yes, $0=$ No
44,569
0.07

\section{$\begin{array}{lllll}44,569 & 0.46 & 0.50 & 0 & 1\end{array}$}

$\begin{array}{llll}1.36 & 3.47 & -2 & 13.5\end{array}$




\section{Endnotes}

${ }^{1}$. Wearing a campaign badge or sticker could be a badge or sticker from a political party or candidate and would accordingly fall under institutionalized political participation but it could also be a badge or sticker from a campaign from for example an NGO that accuses public officials in which case it would count as non-institutionalized political participation. Contacting a politician could be an individual act of a constituent questioning the position of his or her representative, but it can also be an organized and coordinated action of a protest group.

${ }^{2}$. Comparable household income data on Portugal is not available in the fifth round of the ESS. Portugal is therefore left out from the multivariate analysis.

${ }^{3}$. This category consists out of people who are in education, permanently sick or disabled, retired, in community or military service, looking after children or other persons and people who do housework or other activities.

${ }^{4}$ Due to is strong tradition of direct democratic decision making, Switzerland can be considered as an extreme case. Therefore, we have repeated the analysis without Switzerland and we found that the direct effect of the index for direct democracy on voting disappeared. However, also in this smaller sample direct democracy was moderating the relationship between tertiary education and non-institutionalized participation and the effect of income on non-institutionalized political participation. Our main conclusions therefore remain unchanged. 